University of Nebraska - Lincoln

DigitalCommons@University of Nebraska - Lincoln

Textile Society of America Symposium

Proceedings

Textile Society of America

2020

\title{
Coming Together Again: A Case Study on Persian Silk Woven Textiles
}

Tayana Fincher

Rhode Island School of Design, tayana.fincher@gmail.com

Follow this and additional works at: https://digitalcommons.unl.edu/tsaconf

Digitadrt of the Art and Materials Conservation Commons, Art Practice Commons, Fashion Design Commens, Fiber, Textile, and Weaving Arts Commons, Fine Arts Commons, and the Museum Studies Netwerkns

Logo

Fincher, Tayana, "Coming Together Again: A Case Study on Persian Silk Woven Textiles" (2020). Textile Society of America Symposium Proceedings. 1142.

https://digitalcommons.unl.edu/tsaconf/1142

This Article is brought to you for free and open access by the Textile Society of America at DigitalCommons@University of Nebraska - Lincoln. It has been accepted for inclusion in Textile Society of America Symposium Proceedings by an authorized administrator of DigitalCommons@University of Nebraska - Lincoln. 


\title{
Coming Together Again: A Case Study on Persian Silk Woven Textiles
}

\author{
Tayana Fincher \\ tayana.fincher@gmail.com
}

A group of five previously unconnected Persian silk textiles, located at the RISD Museum, Textile Museum in Washington, D.C., Yale University Art Gallery, and the Victoria and Albert Museum share strikingly analogous mihrab motifs, tonally woven patterns, and colors - and perhaps origin stories. Catalogued names for this subset vary from RISD's brocaded satin, originally entitled "traveling prayer rug," to "woven panel," "prayer panel," and "prayer mat." Each textile has a unique provenance record, but the presence of a particular mihrab style signals a clear connection, and each object points to Persia as its source.

This new research cluster provides scholars and textile artists an opportunity to better understand how knowledge might have passed between weavers, workshops, and generations throughout early modern Central and Southern Asia. This case study also touches on provenance histories, featuring donors who make up a bulk of museum collections around the world.

In this paper I pose several questions and hypotheticals stemming from these textiles, which supposedly have date ranges falling between 1600 and 1880 . They are currently housed at distinct institutions, too; either teaching or encyclopedic museums in the United States of America and the United Kingdom. Through these questions, I ask that the the validity of the textiles' attributed dates, object titles, and originating sites be reconsidered, as well as the pertinence of our digital age and how it has perhaps made it more possible to remotely study products of specific workshops and artisans.

I thus start with one of the first Islamic textiles I encountered after beginning my fellowship at the RISD Museum in 2018 (Illustration One). It is an illustrious and silky smooth woven textile with muted colors that were surely more brilliant when it was first made. Many of the motifs and symbols from introductory studies in Islamic art, such as the cypress tree or mihrab found in mosques to point towards the direction of Mecca, feature prominently on it, and also echo in the monochrome damask-like structure.

Speaking about the textile with my colleague began as an attempt solely to figure out an appropriate object title for a gallery rotation related to silk trade relations between Europe and Asia. But, through happenstance and curiosity it became part of a larger, comparative whole. These five extiles were "discovered" through guidance from exhibition catalogues, unrelated flipping through collection manuscripts, and exploring digitally accessible museum websites. Although Persia is listed as the origin for each object in this case study, the attribution seems too broad, so the overwhelming diversity of Iran is important to address. ${ }^{1}$

\footnotetext{
${ }^{1}$ I often switch between using "Iran" instead of "Persia" throughout this paper. Although "Iran" was not the globally recognized name of the country until the Pahlavi dynasty, I believe it centers native thoughts, languages, and traditions as opposed to "Persia," which was more or less imposed on the region by Europeans.
} 


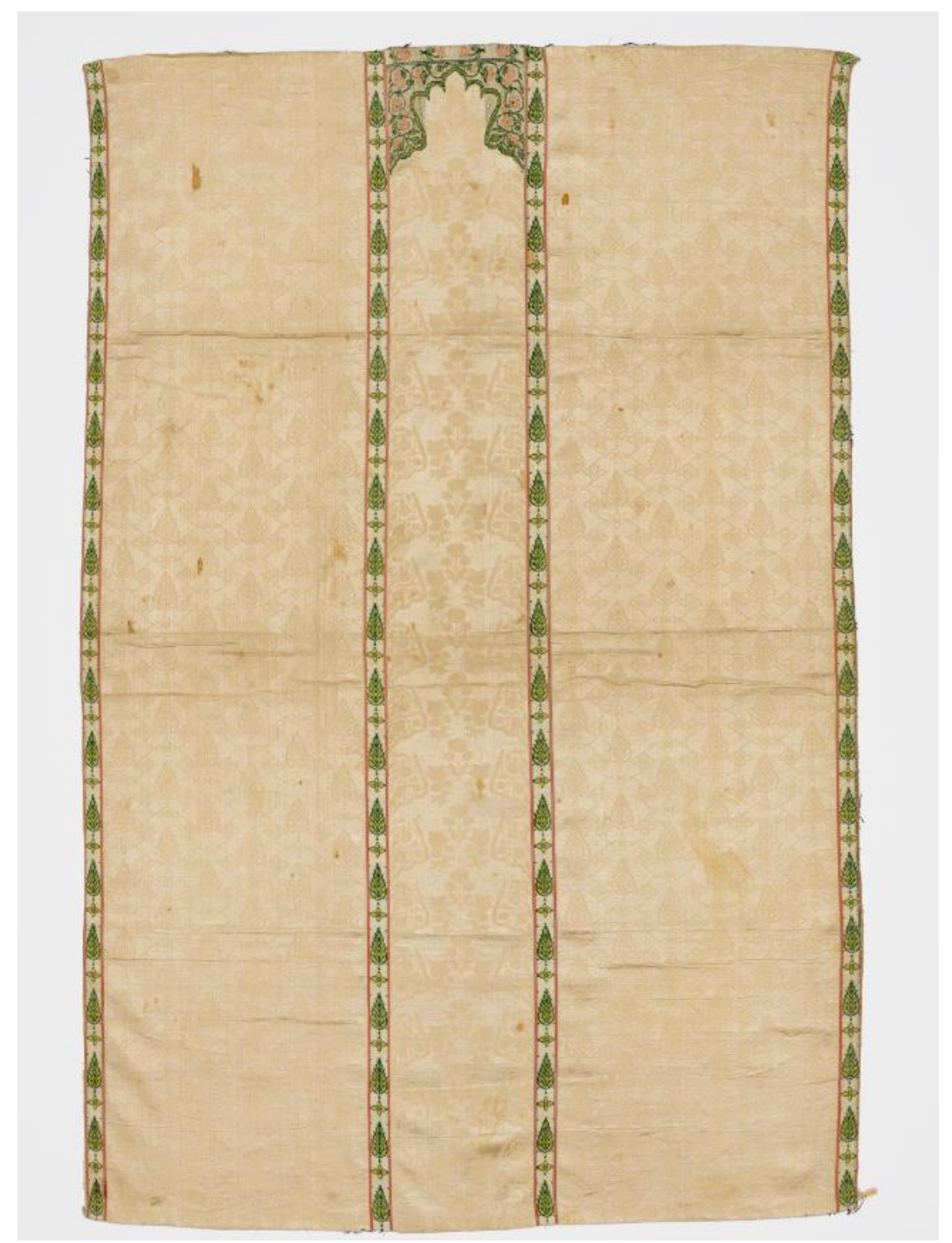

Figure 1. Textile with Mihrab Design, 1700s, 17.039, RISD Museum. Gift of Mustapha Avigdor. (C RISD Museum

An amalgamation of diverse peoples and artistic traditions led to significant arts patronage in early modern Iran between the sixteenth and nineteenth centuries, a large span of which was ruled by the Safavids (1502 - 1736). In Woven from the Soul, Spun from the Heart, Mary McWilliams suggests that a specific place of production for the Textile Museum's woven panel is difficult to identify. ${ }^{2}$ For the two examples from Yale though, Isfahan and Kashan are posited as potential origins. ${ }^{3}$ Superimposed contemporary national borders in orange below might show why pinpointing one place is nearly impossible, given the vastness of the Safavid dynasty and Persianate culture, and how in flux each population was with neighboring entities (Illustration Two). To further complicate the matter, Philippa Scott suggests that Persian and Mughal artisans often crossed empire borders for commissioned and freelance work, or as subjects, teasing the potential of South Asia as another diasporic location for this group of textiles. ${ }^{4}$

\footnotetext{
${ }^{2}$ Mary McWilliams, in Woven from the Soul, Spun from the Heart: Textile Arts of Safavid and Qajar Iran: 16th19th Centuries, ed. by Carol Bier (Washington, D.C., The Textile Museum, 1987), 278.

${ }^{3}$ Yale University Art Gallery Record shared by Ami Potter through email exchange, June 18, 2019.

${ }^{4}$ Philippa Scott, The Book of Silk (London: Thames \& Hudson, 1993), 14, 64.
} 


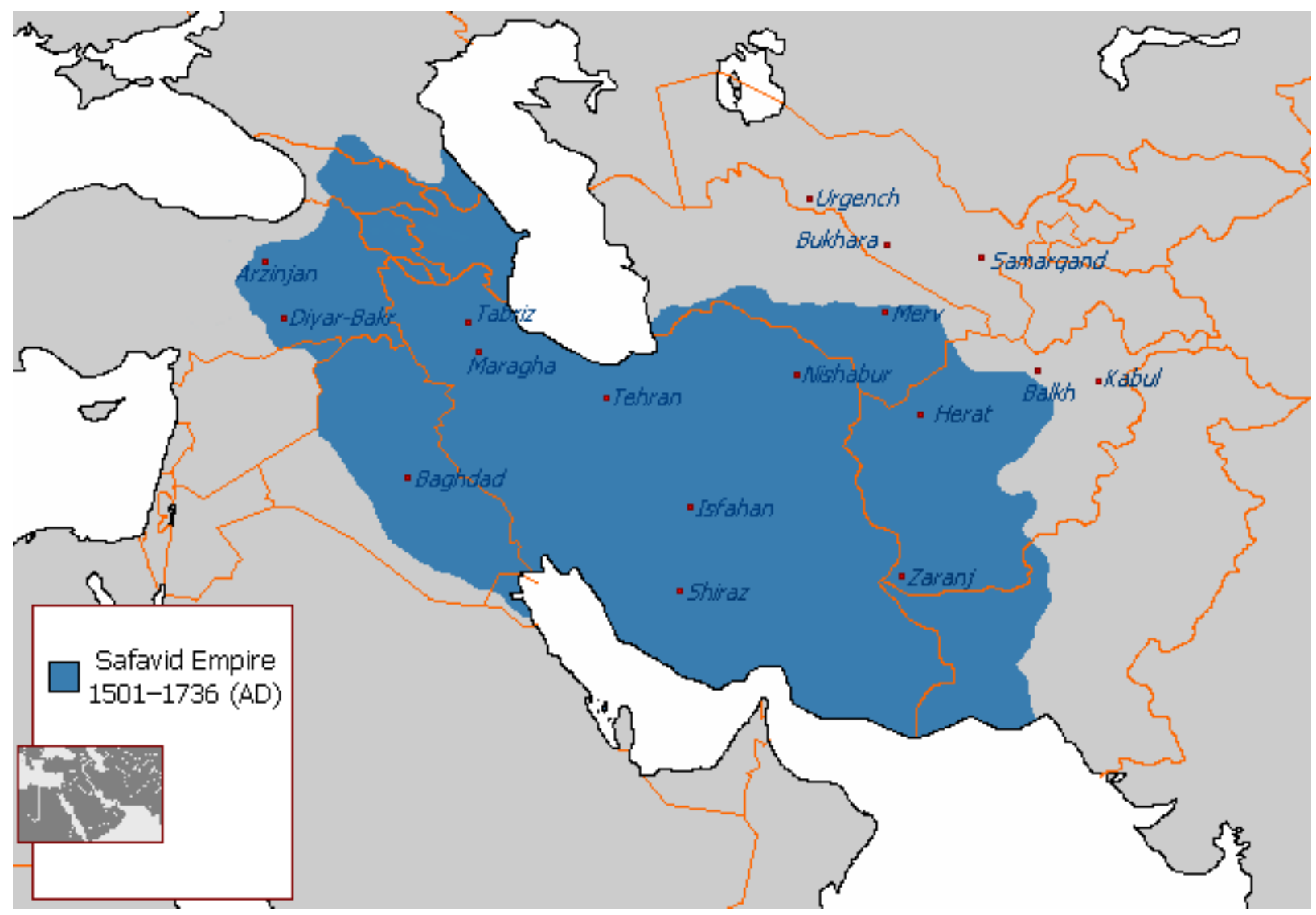

Figure 2. The maximum extent of the Safavid Empire under Shah Abbas I (Wikimedia Commons)

In the early modern period there were many forms and directionalities of Islam, a religion that has adapted to and engaged with countless cultures and ancient histories over the past several hundred years. The Safavid dynasty had assorted relationships with their Ottoman and Mughal neighbors between the sixteenth and eighteenth centuries, as well as those from the Caucasus. Despite evidence of multiculturalism in creative production, such as Georgian and Armenian weavers making up royal ateliers in Safavid courts, the prevailing Eurocentric purview of European and American museums has resulted in little being recorded about specific makers of Islamic textiles.

Many objects, ranging from textiles to manuscripts, were produced by collective royal workshops with many contributors, and were intended for devotional use inside private, domestic spaces. With colonial ventures, objects passed through the hands of collectors and dealers only interested in their material or aesthetic value. With this decontextualization and uncertainty so engrained in the history of Islamic art, I hope this group of five textiles brought together either again or for the first time - can reveal the complexities of global textile making, as the biennial symposium theme suggests.

As a small counter argument though, not attributing makers to objects is not necessarily abnormal. A number of master artisans from medieval and early modern periods are known by their signatures, such as Abu'l Hasan and Bihzad as miniature painting specialists. On the other hand, textiles — even from the early twentieth century — often do not have makers' names 
collected by tourists, who would then go on to become museum donors. This could be an un/intentional result of colonial supremacy in the field of collection building, but it is also an idea native to Islam as a religion and way of life. Names were not always important to the final result, which was a functional object and not an artwork as they read now in museums. Intentionality was instead centered on making something beautiful and pleasing to God. This may help correct the common misconception that Islamic art cannot be figural; it is mostly within a religious context that humans must be cognizant of the fact that they are fallible and cannot create life as God does. ${ }^{5}$ So while the lack of names might be an outcome of imperialism, it is not our only challenge in finding out who first made, used, and lived with these textiles.

This case study begins in Brookline, Massachusetts, with a popular dealer and gallery owner in the Boston area named Mr. Moustapha Avigdor. In 1917, he gifted an eighteenth-century cotton and silk textile to the RISD Museum, as well as other fragments, and his generosity extended around the U.S. in the form of gifts and exhibitions. The RISD textile is made up of one vertically oriented length with raw cut side edges folded over but not sewn down. One selvedge exists at the top, and there is no backing. Although the textile is oriented from top to bottom by virtue of the vertical mihrab, the warp was woven at a right angle to the niche. The white-onwhite damask-like pattern is created by a cotton and silk compound weave structure, while discontinuous supplemental silk wefts in green, yellow, salmon pink, and blue delineate the palmette-shaped mihrab (Illustration Three).

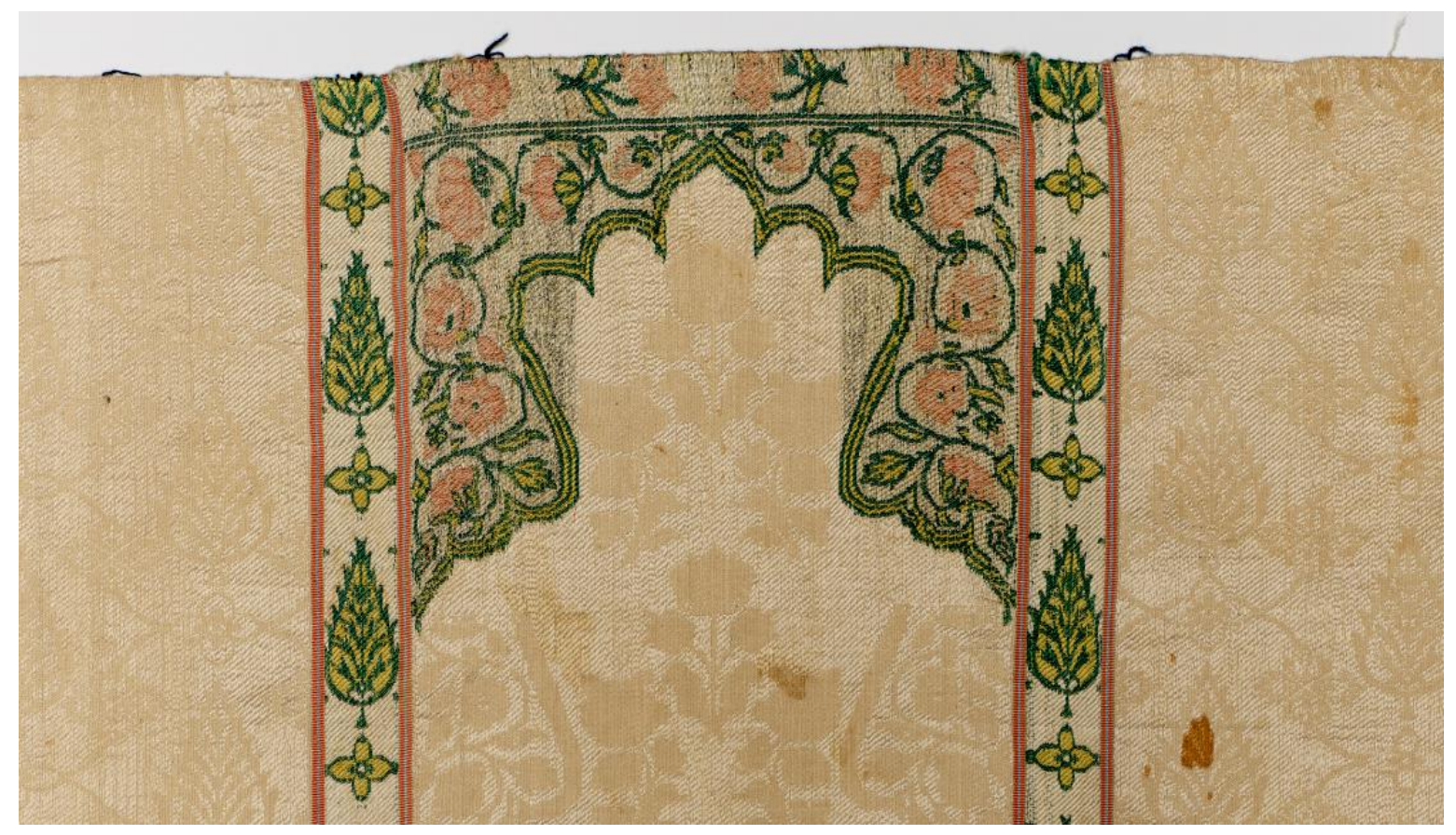

Figure 3. Magnified detail of mihrab structure in Textile with Mihrab Design, 1700s, 17.039, RISD Museum.

The discontinuous wefts also seem to function as a decorative scheme in the outermost lobes of the niche, giving an architectural or three-dimensional appearance. Surrounding the niche are undulating tendrils of pale pink roses and buds, and beneath the mihrab is a narrow tonally woven pattern consisting of ghostly poppies or roses. An inverse echo of the mihrab's sides

\footnotetext{
5 The Hadith (Sahih Muslim, Book 24, Hadith Number 5268).
} 
continue along the edges of the white center portion, varying from the external patterns of stately cypress or sarv motifs. This piece entered the RISD Museum collection with records indicating linen and silk material, but a recent fiber analysis in October 2020 revealed that it is actually cotton and silk (Illustration Four).

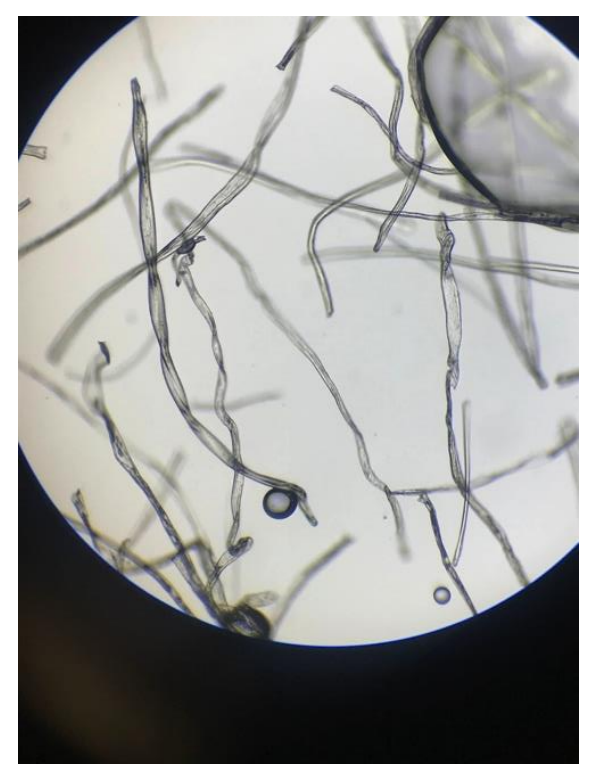

Figure 4. Fiber analysis of cotton weft by Assistant Conservator, Anna Rose Keefe, taken with a Dinolite Pro AM4111T Handheld Digital Microscope on October 8, 2020

Original intake documents title Mr. Avigdor's gift a "traveling prayer rug." Until this piece though, I had never seen the term "traveling" used to describe historic textiles. Initial thoughts centered around Avigdor trying to upsell his antiques, titling it as this to further convince buyers of its idiosyncrasy. A colleague at the Ashmolean Museum agreed that this was incorrectly characterized as such, which resulted in the name change to "Textile with Mihrab Design" for its gallery rotation. On the other hand, a visiting artist to RISD from the United Arab Emirates mentioned to me after a gallery tour featuring this object that her grandmother had in fact owned thin traveling prayer rugs similar to it. Was this then a real textile phenomenon and type, and did it originate in Iran since other Gulf states profess use of it as well? The textile's suspicious title and the lack of a specific origin within Persia's extensive region set off an array of questions and potential avenues.

The RISD textile's eighteenth-century date most likely aligns it with the end of the Safavid dynasty, whose control over the production and sale of silk was already dwindling. With the siege of Isfahan in 1722, and the general decline of the dynasty over the next 14 years, people in the city suffered and starved. This included large numbers of Armenian, Georgian, and Iranian silk weavers altogether, since Safavid patrons sought value in neighboring subjects and styles as well. With this violent end to a successful era of raw sericulture and monopoly, it is likely that the loom weaving traditions and knowledge noted in this group of textiles were lost to the world, 
or at least went off in different directions with weavers changing professions to fit new economies and tastes.

With the apparently youngest textile in this case study — from the V\&A — dated to the late nineteenth century, it might make sense then that only the mihrab structure would exist in this compositely decorated form. In detail photographs, the niche appears as though it was abruptly included (Illustration Five). But, the V\&A prayer mat was woven continuously and not pieced together. It too shows the use of cypress trees in the flanking albeit polychrome areas, making it similar to the RISD example. Differences include a roller-printed cotton layer backing, the color being apparently carried in the warp, and the mihrab holding a fiery nimbus shape in its center lobe (Illustration Six). This motif was used to signal prophethood and significance in book arts, so it may serve a related function here.

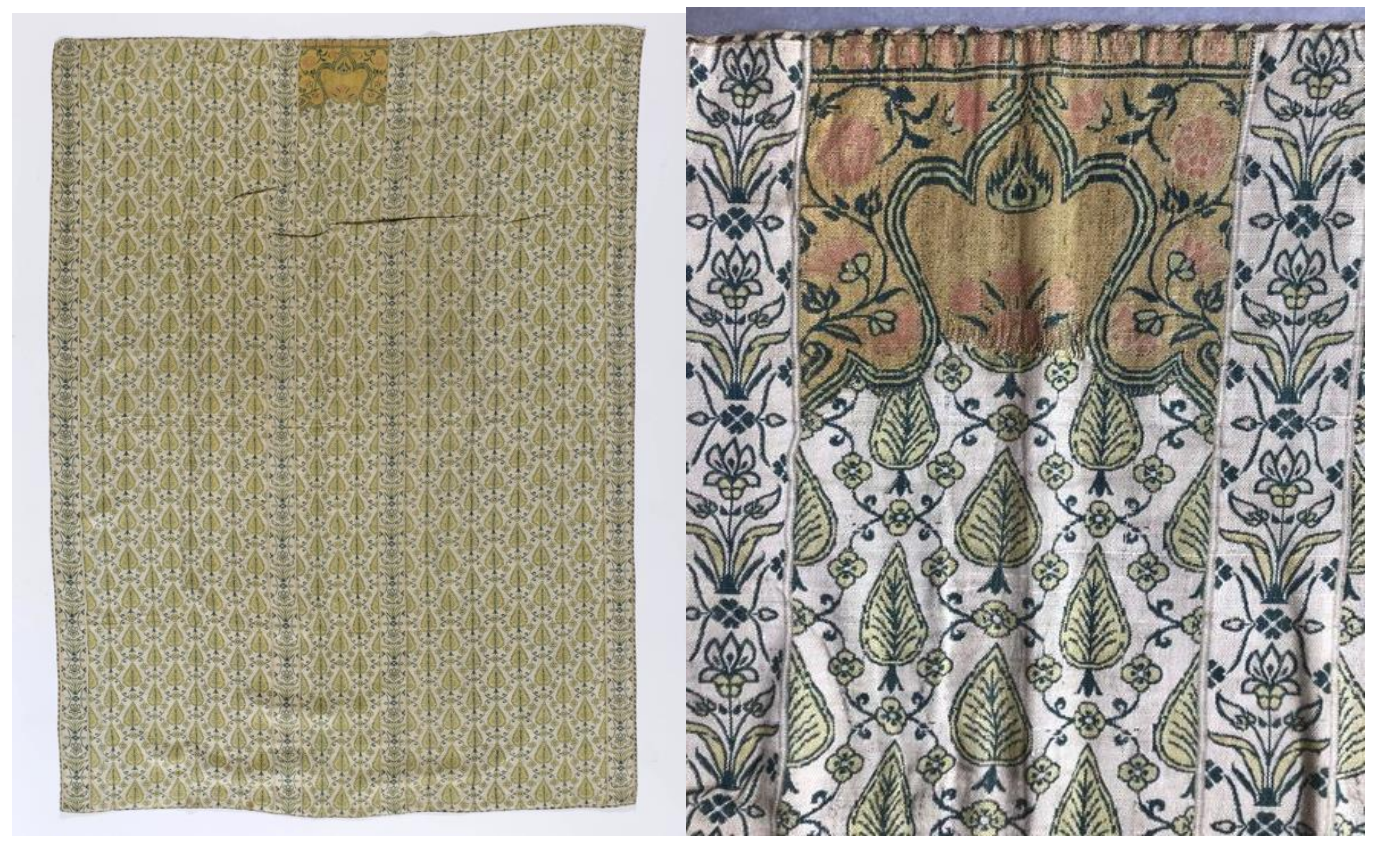

Figure 5 and 6. Prayer Mat, 1800 - 1880, 36 in x 54.3 in (91.5 cm x $138 \mathrm{~cm})$, Victoria and Albert Museum, London, 1435-1903, and detail image of the mihrab. (C) Victoria and Albert Museum, London.

Continuing in the lineup for this case study, I now address the textile mentioned in Carol Bier's 1987 catalogue for the Textile Museum (Illustration Seven). The eighteenth- to nineteenthcentury prayer panel was gifted in 1956-57 by Mrs. Hoffman Philip in honor of her late husband. He was an American ambassador to Persia in the 1920s, right after the installation of the Pahlavis, the last dynastic family of Iran. ${ }^{6}$ Mrs. Philip seems to be one of the earliest object donors to the Textile Museum, given that all other pieces came from the museum's founder.

6 “Hoffman Philip (1872-1951)." U.S. Department of State, Office of the Historian. 


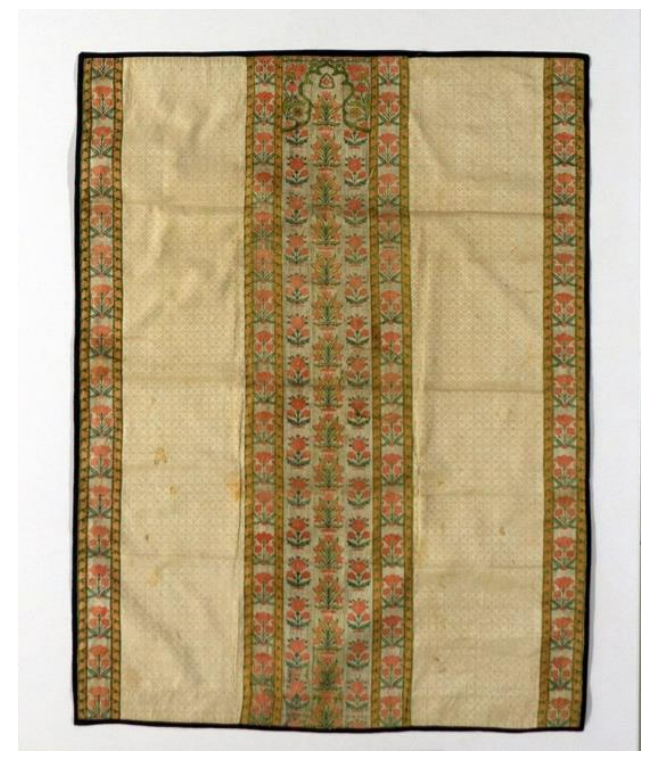

Figure 7. Iran, Woven Panel, 1700s - 1800s, 32.5 in x 43 in (82.7 cm x $108.3 \mathrm{~cm}$ ), Gift of Mrs. Hoffman Philip, 3.340. (C) The Textile Museum.

This woven panel differs from RISD's in that it is stitched together from three fragments, and its center is embedded with far more stylized and multicolored flora. The panel is a plain weave with complementary wefts and inner warps, and was also woven at a right angle to the mihrab, which here appears more elongated (Illustration Eight). In terms of details, like RISD's "Textile with Mihrab Design" there is glossy white on matte white in the ground, and the color is carried in the wefts. There were no pictures of this object on the Textile Museum website when initially researching, so an in-person assessment was required.

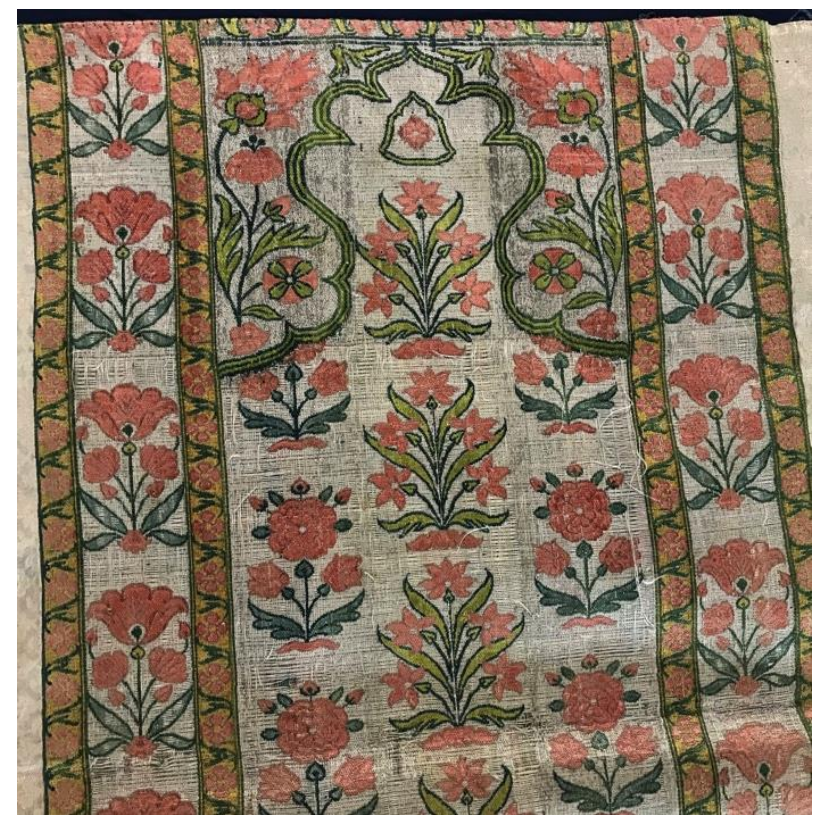

Figure 8. Magnified detail of mihrab structure in Woven Panel, 3.340, The Textile Museum. Photo courtesy of Tayana Fincher. 
The back is partially inaccessible because of a cotton backing, and there are a few notable stains on the larger whole, perhaps from a drink or inkwell (Illustration Nine). The woven panel entered the collection with this backing, so the stains' developments can be speculated; perhaps they were contemporaneously included with the mihrab pattern on the front, and a pious Muslim accidentally laid the panel down over a ring of liquid on the ground. Or maybe someone in the line of donors used the textile as a table cover to accompany their morning drinks. With little documentation, this cannot be known. Considering the levels of cleanliness required before daily prayers in Islam though, if this is in fact for devotion, the stains lead one to wonder about the treatment of textiles and varied contexts from which they come.

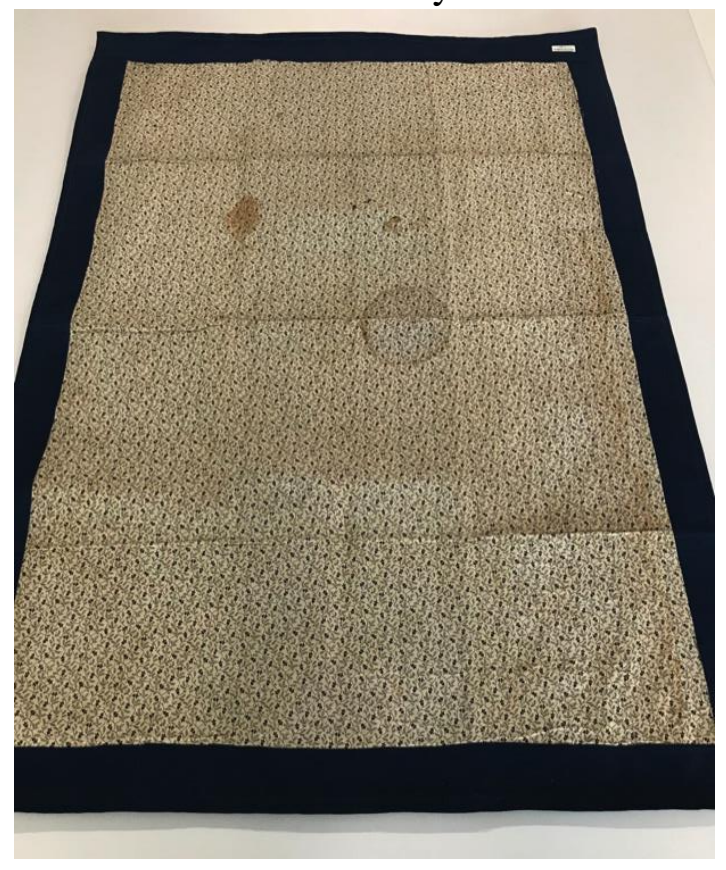

Figure 9. Detail of backing in Woven Panel, 3.340, The Textile Museum. Photo courtesy of Tayana Fincher.

This panel shares some similarities with the RISD and V\&A textiles. As in the RISD object, the Textile Museum panel has a five-lobed mihrab delineated by alternating lines of green and yellow threads. Like the V\&A prayer mat though, the polylobed niche holds a tiny pattern in its center. A bell-shaped motif encloses a four-petaled flower, and the mihrab is surrounded by an intricate array of pink and yellow flora. In the Q\&A session of a recent virtual conference entitled Textiles on the Move, Sumru Belger Krody posited that the Timurid Empire, succeeded in part by the Safavids, and their design choices were popularized in both Persia and Anatolia, ${ }^{7}$ such as an attention to lilies and tulips. A lily, tulip, or rose may be represented in the woven panel's vertical patterns, ${ }^{8}$ but regardless of flora type the color choice remains generally identical, focusing on pinks, greens, and yellows. This decision is interestingly and slightly defied by one of the Yale University Art Gallery textiles, though.

These two seventeenth-century prayer panels, the last of this grouping, were gifted to Yale in 1937 by Mrs. William H. Moore (Illustration Ten and Eleven). She was an avid collector of

\footnotetext{
${ }^{7}$ Sumru Belger Krody, Textiles on the Move, "Beauty \& Purpose, Prayer Carpets and their Design Impact," virtual presentation by Sumru Belger Krody, October 6, 2020.

${ }^{8}$ Mary McWilliams, Woven from the Soul, 278.
} 
Asian art and antiques from the Mediterranean to China, and was considered a "foster mother" to Arthur Upham Pope and Phyllis Ackerman, of whom's collection the panels were previously in. Ackerman and Pope were important and at times controversial twenthieth-century dealers, scholars, and archaeologists of Iranian art, and they were heavily supported - both platonically and financially - by Mrs. Moore, whose husband was involved with law, finance, manufacturing companies, oil, steel, and railroads. The prayer panels are supposedly the earliest objects in this case study, perhaps aligning with the height of the Safavid monopoly on silk under Shah 'Abbas. The first panel was noted in the Woven from the Soul catalogue as being comparable to the Textile Museum panel, but the second object has an incredibly strong semblance to RISD's "Textile with a Mihrab Design."

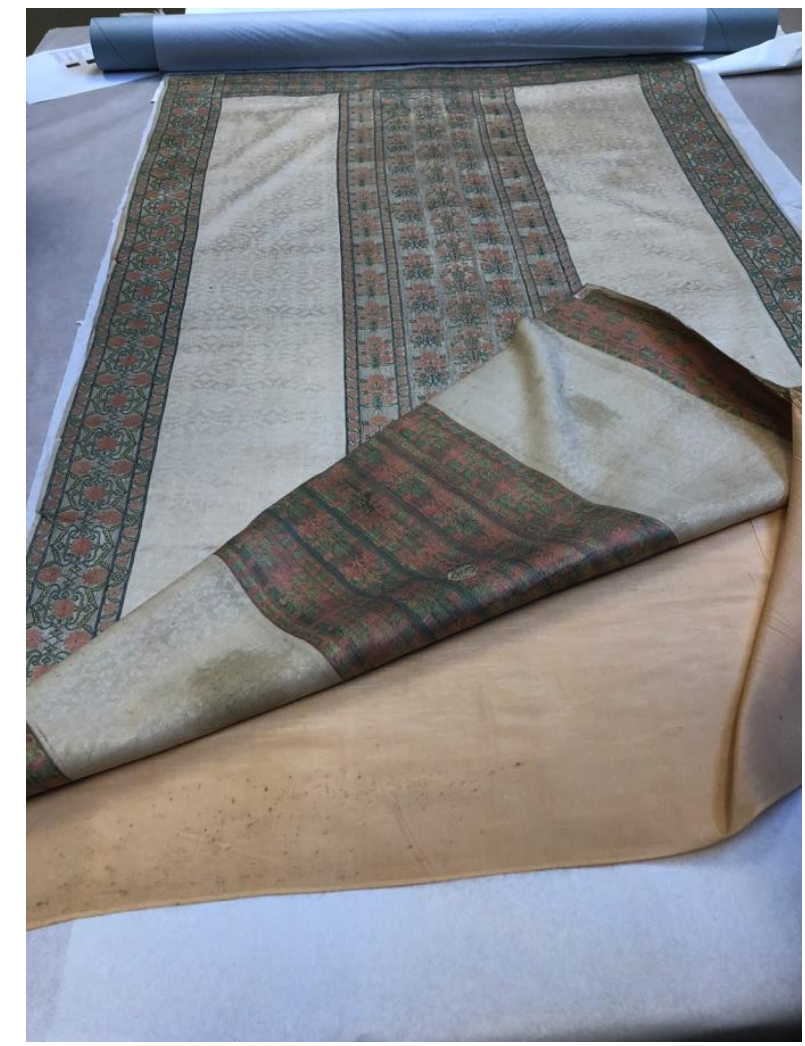

Figure 10. Iranian/Persian, Islamic, Prayer Panel, 17th century, 58 in $x 37$ in (147.3 cm x $94 \mathrm{~cm})$, Hobart and Edward Small Moore Memorial Collection, Gift of Mrs. William H. Moore, 1937.4767, Yale University Art Gallery. Photo courtesy of Laurie Anne Brewer. 


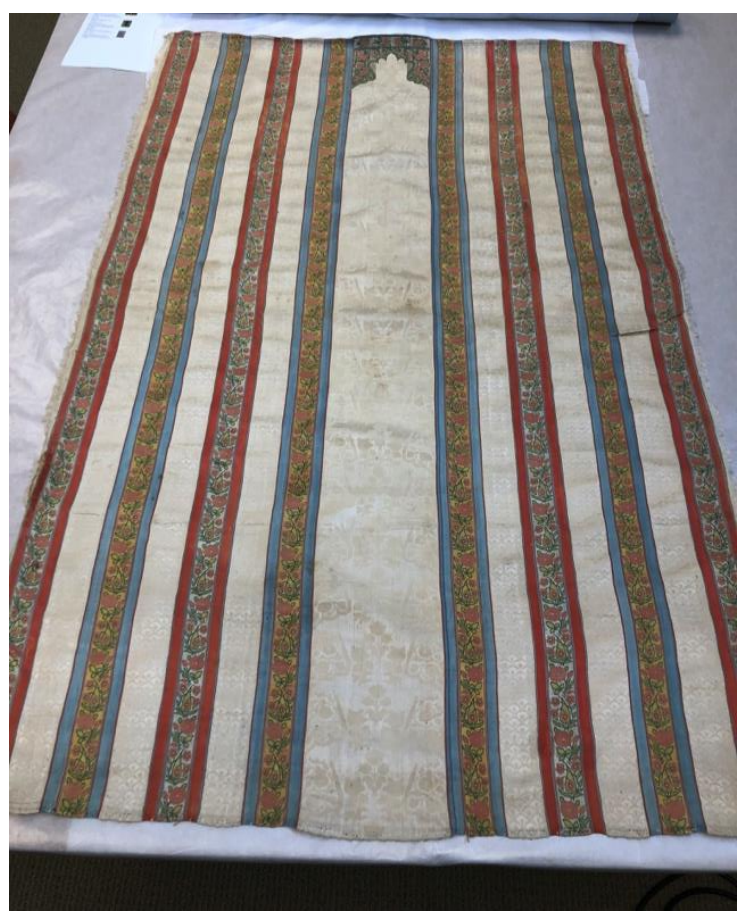

Figure 11. Iranian/Persian, Islamic, Prayer Panel, 17th century, 56.5 in $x 37$ in (143.5 cm x $94 \mathrm{~cm})$, Hobart and Edward Small Moore Memorial Collection, Gift of Mrs. William H. Moore, 1937.4768, Yale University Art Gallery. Photo courtesy of Laurie Anne Brewer.

Considering the discussion about identical color palettes, the second prayer panel has the additional vibrancy of reddish pink and blue along the thin ribbons of flora. I fortuitously found this textile while digitally searching for the first Yale panel, and was incredibly happy to see clear connections to the RISD length. From detail images an almost identical niche decoration is visible, in terms of the multifoil arch, dark discontinuous wefts in the outer lobes, inward facing flowers along the top banner, and flowing vines around the mihrab (Illustration Twelve).

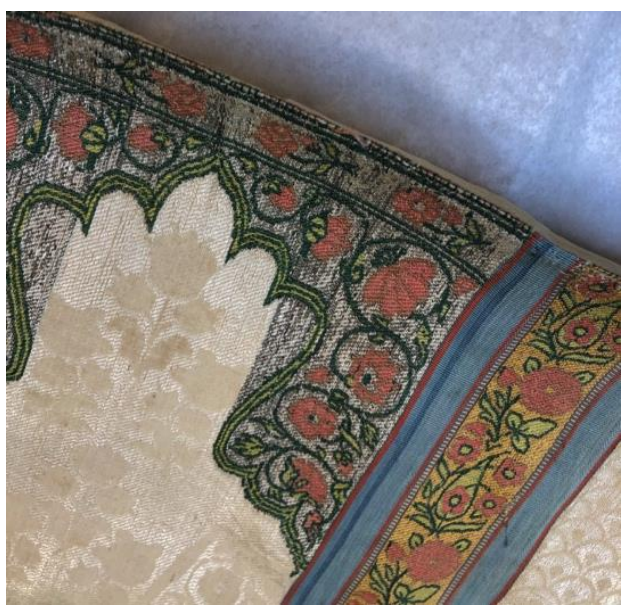

Figure 12. Detail images of mihrab in Prayer Panel, 1937.4768, Yale University Art Gallery. Photos courtesy of Laurie Anne Brewer. 
Notice the same design, too, in the center underneath the niche with the three-bulbed flower at the top, and upside down mihrab echoes along the colorful borders (Illustration Thirteen). Although the Yale and RISD textiles are technically dated to subsequent centuries, the mihrab treatment might be another indicator of descendant knowledge on loom patterns across time and/or generations, or a marker that institutions have not yet properly dated these. More detailed analysis shows that the prayer panel was woven fully across as one piece, which is evident despite its backing. There are also what appear to be carnations and droplet patterns, most likely characterized as stylized boteh motifs, which might suggest South Asian makers, visual cultures, or conventions were involved in the creation of these textiles.

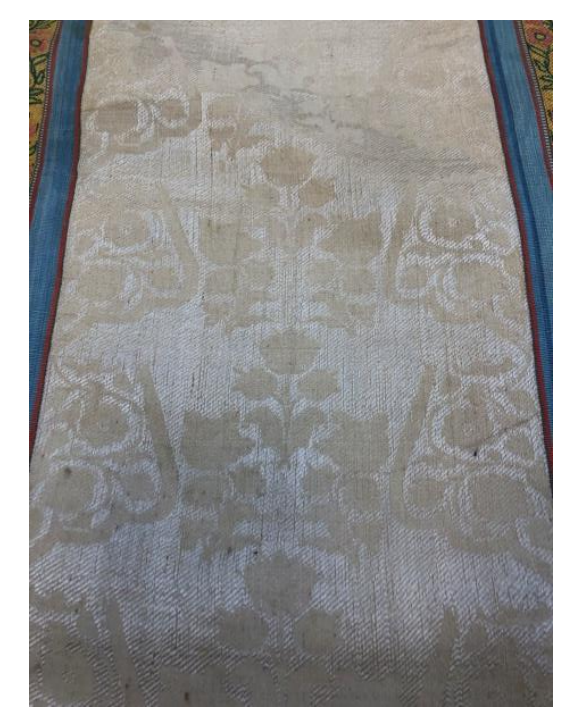

Figure 13. Detail images of mihrab and center section in Prayer Panel, 1937.4768, Yale University Art Gallery. Photos courtesy of Laurie Anne Brewer.

As for the other Yale example, this is the first textile in the case study with a border along the full top of its width (Illustration Fourteen). Each inches-wide border is heavily embedded with pink flowers, including the center, similar to the Textile Museum panel. 


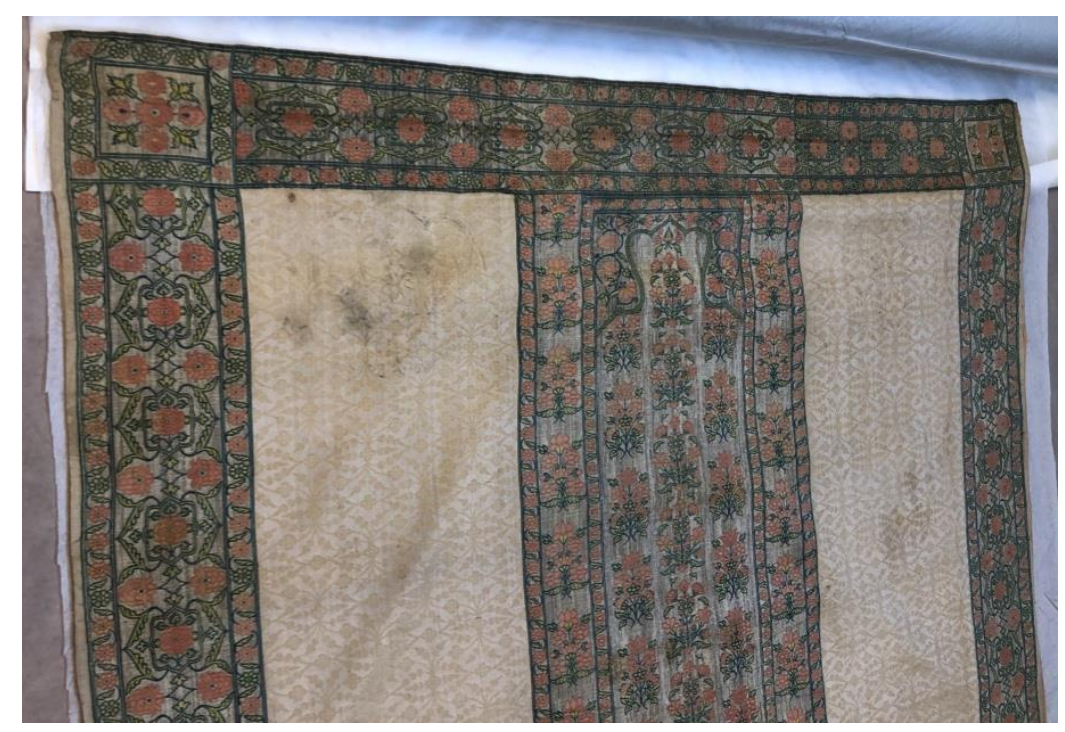

Figure 14. Detail image of mihrab and borders in Prayer Panel, 1937.4767, Yale University Art Gallery. Photo courtesy of Laurie Anne Brewer.

Focusing on the mihrab, the common color palette between the five textiles is again clear, alongside oscillating vines around the niche, but there are some profound differences as well. Leaves occupy the corner of this mihrab instead of a rose, and although there is a line of pink flowers along the uppermost section of the niche - as in the red and blue Yale panel - the convention only repeats around the full scope of the Yale panel below. Another divergence is the three-lobed arch instead of five, associating it with the early to late nineteenth-century V\&A prayer mat. Furthermore, the nimbus or halo motif is also present at the top center of the niche, implanted in a leafy or flowery shape (Illustration Fifteen). Without the floral elements, the flaming pattern here and on the V\&A prayer mat possibly trace a change in representation over the perceptible two to three hundred years between the two textiles.

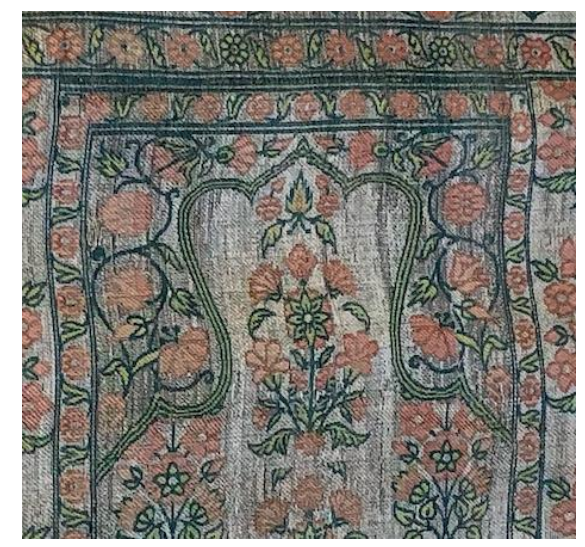

Figure 15. Detail image of mihrab and borders in Prayer Panel, 1937.4767, Yale University Art Gallery. Photo courtesy of Laurie Anne Brewer

Moving deeper inwards, there are elaborate bouquets of flowers all over. Visible near the bottom polychrome center are metallic thread chainstitches, possibly used as an embellishing mend 
(Illustration Sixteen). The outer edges of the panel consist of flowers inside and around cartouches, and the top corner squares are embedded with a separate symmetric design.

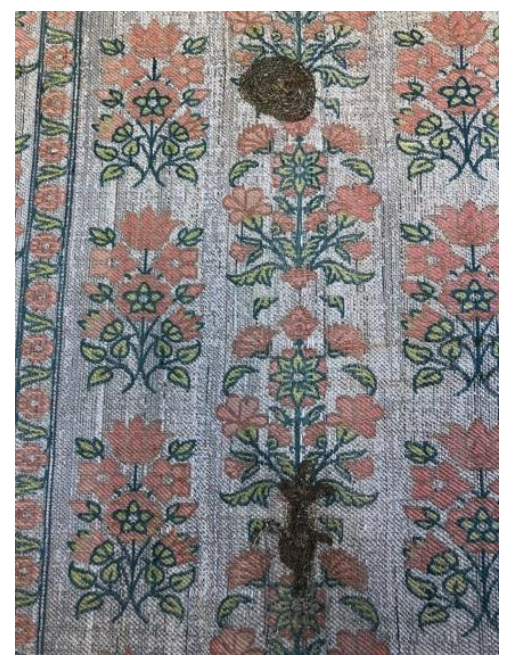

Figure 16. Detail image of metallic thread additions in Prayer Panel, 1937.4767, Yale University Art Gallery. Photo courtesy of Laurie Anne Brewer.

Differing from all other textiles in the case study, the top left monochrome section of this prayer panel has distinctly unnatural dark spots (Illustration Seventeen). Contrary to earlier potentials regarding users having dropped liquid onto the textile, it appears as if someone intentionally tried to stencil or copy the center mihrab shape onto the white ground. By speculating, is it possible that the graphite markings were drawn by its donor, Mrs. Moore, or perhaps earlier by Ackerman and Pope? Or even after Yale acquired it, perhaps by a University Art Gallery staff member in the 1940-50s? This might then lead to further reconsideration about the metallic thread as well, considering how surprising its inclusion is. Taking it further, were the markings added well before the panel even entered the North American continent, perhaps used as a practice length in originating weaving workshops? With minimally detailed object files, this is again just speculation. 


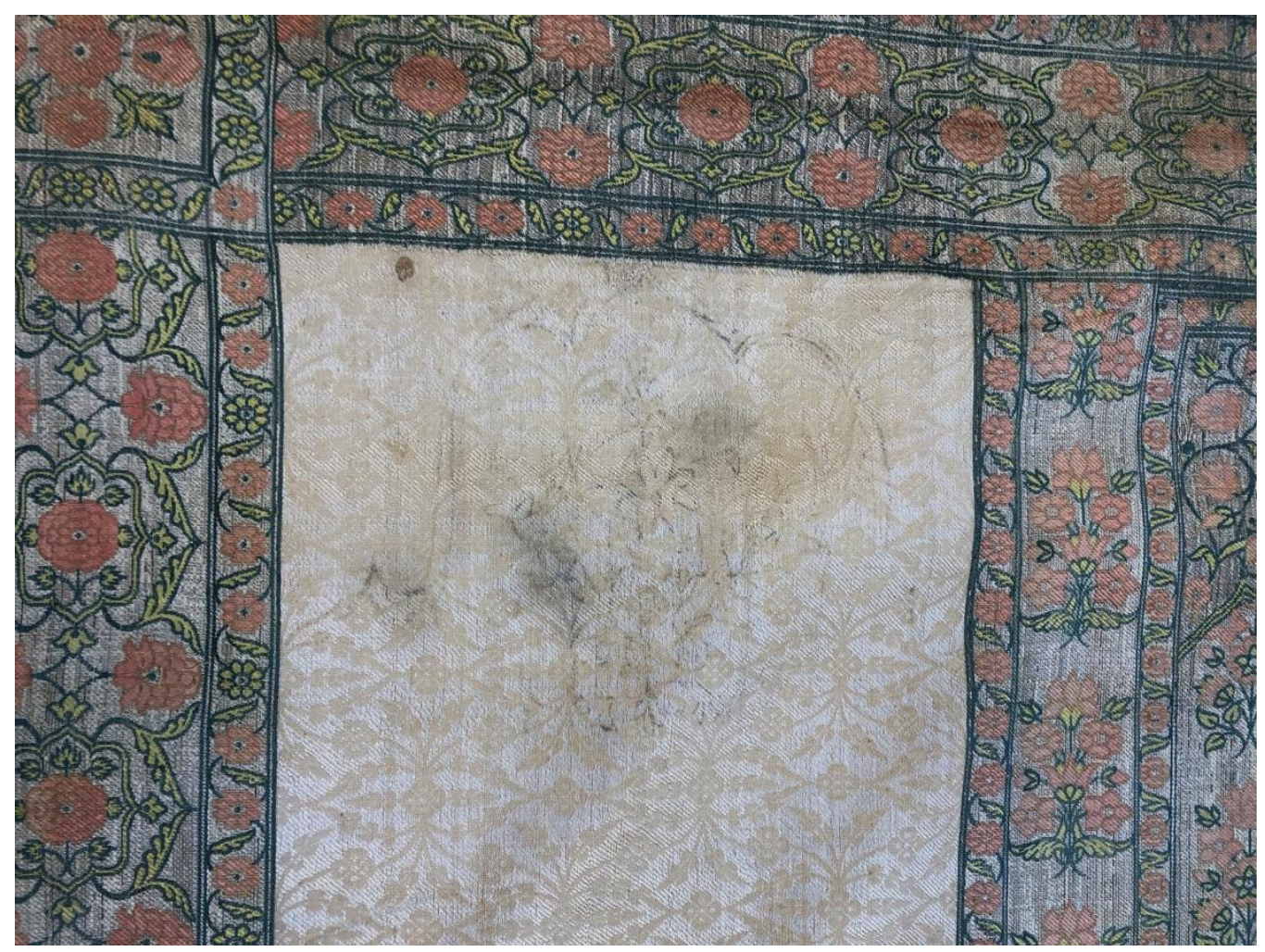

Figure 17. Detail image sketching in monochrome section in Prayer Panel, 1937.4767, Yale University Art Gallery. Photo courtesy of Laurie Anne Brewer.

Out of these five textiles with various titles related to prayer, by means of prostrating on top of it or hanging it on a wall as a devotional panel, many have browned stains, repairs, or pencil markings that suggest mistreatment or negligence either before or after they entered museum collections. The Qur'an dictates that washing ( $g h u s l$ ) and cleanliness are required before presenting oneself to God in prayers. In addition to the body being properly prepared, outward conditions must be as well, including the prayer carpet and general environment. Usual signs of wear on rugs might be understandable, such as dyed spots on the surface where the praying person's knees would lie, or deep impressions on thicker pile carpets, but these examples seem to speak to the potential of dealers and donors altering sacred pieces.

Although this study has yielded several more questions and concerns than answers, the prospect of these textiles undergoing further research is exciting, especially when borders open up and site visits becomes possible again. Various correlations and discrepancies exist between these five objects, which according to their institutions again span from 1600 to 1880 . Since the earliest examples apparently fall right at the height of Safavid silk patronage under Shah 'Abbas, I wouldn't necessarily reject the idea of Isfahan or Kashan being source locations for these textiles. But, as we consider the breadth of people, cultures, and histories that made up the Safavid dynasty, it may be worth thinking about weavers and conventions from what is now Iraq, Turkey, Armenia, Georgia, Azerbaijan, Turkmenistan, Afghanistan, Pakistan, and India, and what knowledge they might have imparted on populations and diasporas in Iran. 
Like the fluidity of borders today and the great number of people migrating by choice or force, one can imagine diasporic and economic movement making these collaborative textile patterns possible, but more analysis is necessary to obtain solid answers. In the meantime though, reassessing the given attributes of these textiles and imagining the several uses of them - by native makers, dealers, and host institutions - might elucidate further connections between the grouping. The notion of immigration into and emigration between Central and Southern Asia has been a topic of inquiry for a while, ${ }^{9}$ so as more information is gathered on similar textiles either in collections or in personal homes, there should be little in the way of tracing ties. Hopefully, too, with new digitization efforts amidst global lockdowns and travel restrictions, virtual access will continue increasing and data will be shared at greater frequencies.

\footnotetext{
${ }^{9}$ Masashi Haneda, "Emigration of Iranian Elites to India during the 16-18th Centuries," Cahiers d'Asie Centrale [En ligne], 3/4 | 1997, mis en ligne le 03 janvier 2011.
} 


\section{Bibliography:}

Belger Krody, Sumru. "Beauty \& Purpose, Prayer Carpets and their Design Impact." Textiles on the Move, virtual conference by the International Institute of Asian Studies (IIAS), Tracing Patterns Foundation, and Textile Research Centre, October 6, 2020. https://www.iias.asia/the-newsletter/article/textiles-move-online-meeting

The Hadith (Sahih Muslim, Book 24, Hadith Number 5268). http://www.hadithcollection.com/sahihmuslim/Sahih\%20Muslim\%20Book\%2024.\%20Cl othes\%20and\%20Decorations/sahih-muslim-book-024-hadith-number-5268.html

Haneda, Masashi. "Emigration of Iranian Elites to India during the 16-18th Centuries." Cahiers d'Asie Centrale [En ligne], 3/4 | 1997, mis en ligne le 03 janvier 2011. http://journals.openedition.org/asiecentrale/480

Herzig, Edmund M. "The Volume of Iranian Raw Silk Exports in the Safavid Period." Iranian Studies 25, no. 1/2 (1992). www.jstor.org/stable/4310787

Mackie, Louise W. Symbols of Power: Luxury Textiles from Islamic Lands, 7th to 21st Century. New Haven, CT/Cleveland, OH: Yale University Press/Cleveland Museum of Art, 2015.

McWilliams, Mary. In Woven from the Soul, Spun from the Heart: Textile Arts of Safavid and Qajar Iran: $16^{\text {th }}-19^{\text {th }}$ Centuries, edited by Carol Bier. Washington (D.C.): The Textile Museum, 1987.

Steinmann, Linda K. "Shah 'Abbas and the Royal Silk Trade 1599-1629." Bulletin (British Society for Middle Eastern Studies) 14, no. 1 (1987). www.jstor.org/stable/194456

U.S. Department of State, Office of the Historian, "Hoffman Philip (1872-1951)." https://history.state.gov/departmenthistory/people/philip-hoffman 